A N N A L E S

UNIVERSITATIS MARIAE CURIE-SKŁODOWSKA LUBLIN - POLONIA

VOL. XXX, 3 SECTIO J 2017

Maria Curie-Skłodowska University in Lublin. Faculty of Education and Psychology

\begin{abstract}
ANNA WITEK, IZABELLA MARIA ŁUKASIK, AGNIESZKA BUCZAK

anna.witek@poczta.umcs.lublin.pl, izabella.łukasik@poczta.umcs.lublin.pl, abuczak@poczta.umcs.lublin.pl
\end{abstract}

\title{
Reaching for Energy Drinks and Ability to Deal Effectively with Difficult Situations in the Opinion of Students
}

Sięganie po napoje energetyzujące a umiejętność skutecznego radzenia sobie $\mathrm{z}$ sytuacją trudną w opinii studentów

\section{SUMMARY}

Dynamically changing reality poses new challenges to us hence the need to be mobile and dispositional. Consequently, we are reaching for different products that increase our performance often at the expense of our own health. The research was conducted among students of the first year of humanities at the UMCS in Lublin. The questionnaire of authors' own design was used to determine the frequency of reaching for energy drinks by the tested students as well as their tasks and duties. CISS and GSES were used to diagnose styles of coping with stress and self-efficacy. Almost half of the respondents do not reach for energy drinks and one in ten admits to frequently reach for such beverages. No dependence was observed between reaching for energy drinks and the styles used by the respondents in different difficult situations and levels of self-efficacy.

Keywords: energy drinks; coping with difficult situations; self-efficacy

\section{INTRODUCTION}

Thanks to advertising and relatively low prices, energy drinks are often bought and consumed by young people and even children (Waszkiewicz-Robak 2008, p. 71). It is a group of products present in Europe for several years. Approximately, 40 assortments of these products were authorized for sale in Poland in 1995-2002, while in 2006, more than 500 new brands were introduced to the world markets (Reissig, Strain, Griffiths 2009). 
Poles fell in love with energy drinks and in terms of their consumption, they are in the forefront of Europe. Last year we drank more than 140 million liters of "energizers", this year the market value is expected to be by 20 million liters higher. In terms of consumption of this type of beverage per person, Poland is currently in the sixth place in Europe after Austria, Finland or Estonia.

Despite the assurances of manufacturers and some nutritionists about the harmless effects of energy drinks, more and more doubts arise about their use, especially by children and adolescents. Analysis of sale market of such drinks has shown that half of their consumers in 140 countries where they are available, are children and young people (Błaszczyk et al. 2012, p. 33). All energy-providing products contain one or more carbohydrates (for example, in the form of dextroseglucose, starch syrup, maltodextrin, saccharose or fructose) and various types of biostimulants such as caffeine, a nerve stymulant; taurine which affects the proper functioning of the nervous and muscle systems as well as a mildly sedative inositol which improves mental performance and prevents cardiovascular diseases. Some of the energy drinks are also enriched with guarana, a substance that contains about 2.5 times more caffeine than coffee, as much as 2.5 to $5 \%$. Most often, however, one can of $250 \mathrm{ml}$ contains about $80 \mathrm{mg}$ of caffeine/portion. The role of energy drinks is to mobilize the body for greater efficiency. Their ingredients are designed to accelerate the production of energy in cells. According to the producers, after energy drink consumption, mood and concentration improve and strength increases. Vitamins B, which are necessary for the proper functioning of the nervous system, are also often added to energizing products; they are also involved in the process of converting the stocks into energy. Sometimes they also include compounds accelerating metabolism and facilitating fat burning, such as glucuronolactone or L-carnitine (Wierzejska, Jarosz 2011).

In the study by Semeniuk (2011, p. 967) it was alarming that more than $10 \%$ of young people declared that only after drinking 1 liter of energy drink did they feel the expected stimulating effect.

Nutrition specialists pay close attention to the way these products are metabolized. The consumption of beverages containing saccharose (including energy drinks) results in increased energy consumption which in consequence promotes the development of excess weight and obesity. In addition, the consumption of this type of beverage leads to an increase in blood glucose, reduced sensitivity of cells to insulin, decreased feeling of satiety and, therefore, to increased energy consumption (Bajerska et al. 2009, p. 216).

The European research, conducted in recent years, on the health behaviour of young people, showed a statistically significant association between frequent resort to energy drinks and alcohol dependence. The probability of alcohol de- 
pendence of young people who use energy drinks more than once a week is twice more likely than of those that reach for them only occasionally (Arria et al. 2011, pp. 1-9).

Doctors and pharmacists are increasingly citing worrying reports of evidence of harmful, toxic, addictive effects of energy drinks on the body. In particular, attention is paid to the risk of metabolic diseases including diabetes, neurological disorders, depression, growth disorders in children, heart attack, stroke, etc. In addition, these drinks can also cause behavioral changes. Preferred stimulating effect of these products is very short. They do not make the people using them more rested, they do not substitute for sleep. In addition to reaching for other addictive substances (including alcohol and drugs), excessive use of these drinks correlates with aggressive behaviours and risky sexual behaviours (Energetyzuja czy truja? 2011, pp. 38-41).

On the basis of a survey conducted in 2012 on a group of more than 52,000 respondents from $16 \mathrm{EU}$ Member States (14,500 adults, 32,000 youngsters, 5,500 children), the EFSA published a report which first compiled data on consumption of energy drinks in Europe by individual population groups, including children and adolescents. Studies have shown that the largest group consuming energy drinks is youth (68\%). Out of them, $12 \%$ were regular consumers and the average consumption was 7 liters per month, 12\% were sporadic consumers ("Energy" drinks report. Doniesienie prasowe). Similar conclusions are drawn from the research by Łagowska et al. (2011), in which the researchers point out that young people do not eat properly. The most popular Food Forests included eating white bread and sweetened drinks, including energy drinks.

According to the quoted report of the EU Food Safety Agency, 73\% of Polish young people aged 10-18 years drink beverages containing stimulants such as caffeine and taurine (Gathering consumption data on specific consumer groups...).

\section{PURPOSE OF THE STUDY}

Distressing reports from the cited research have contributed to carrying out our own empirical analysis. An important research problem is to find ways to be dispositional, in this case, by means of energy drinks.

The purpose of the study was to try to determine the extent of the phenomenon of reaching for energy drinks by students with different levels of self-efficacy in the context of dealing with daily tasks and tasks in limited time, and other difficult situations.

The following research questions were formulated:

1. What is the size of the phenomenon of reaching for energy drinks by students of the humanities? 
2. Is there and, if so, what is the relationship between reaching for energy drinks and coping with excesses of duty and time pressure?

3. Is there and, if so, what is the difference in dealing with the difficult situation by people who use energy drinks with different frequencies?

4. Is there and, if so, what is the difference in the level of self-efficacy of people using energy drinks with different frequencies?

\section{MATERIAL AND METHOD}

The study was conducted in 2013 among the students of the humanities at the UMCS in Lublin. The research group consisted of 91 women aged 18-25 years.

A self-constructed questionnaire and two standardized tools were used: Questionnaire for Coping with Stressful Situations (CISS) and Scale of Generalized Efficacy Scale (GSES). Questionnaire for Coping with Stressful Situations by N.S. Endlera and J.D. Parker in the Polish adaptation of P. Szczepaniak, J. Strelau and $\mathrm{K}$. Wrześniewski is intended for the study of adolescents and adults. A 48-item questionnaire can be used to diagnose stress management styles, after defining the performance on a 5-step frequency scale. The tool identifies three scales: SSZ - style focused on the task; SSE - style focused on emotions; SSU style focused on avoiding. The latter style can take two forms: ACZ - engaging in substitute activities and PKT - looking for social contacts. CISS is a reliable and accurate tool (Strelau et al. 2005). The Scale of Generalized Efficacy Scale by R. Schwarzer, M. Jerusalema and Z. Juczynski is used to study adults and consists of 10 statements covering one factor. It can be used to determine the general belief of the individual about the effectiveness of coping with difficult situations and obstacles (Juczyński 2000).

A self-constructed questionnaire consisting of over a dozen questions allowed for identifying energy drinkers and determining their frequency of use as well as it indicated situations conducive to use this type of products. Respondents were also asked about awareness of the negative health consequences in a situation of consuming energy drinks, and about groups of people for whom these products are particularly harmful.

\section{RESULTS}

Taking into account the health risks of reaching for energy drinks, the question was: What is the size of the phenomenon of reaching for energy drinks by students of the humanities? 
Table 1. Frequency of reaching for energy drinks $(\mathrm{N}=91)$

\begin{tabular}{|l|c|c|}
\hline \multicolumn{1}{|c|}{ Reaching for energy drinks } & No. of people & $\%$ \\
\hline Never & 45 & 49.5 \\
\hline Hardly ever & 28 & 30.8 \\
\hline Occasionally (no more than once a month) & 10 & 11.0 \\
\hline Several times a month & 3 & 3.3 \\
\hline At least once a month & 3 & 3.3 \\
\hline Daily & 2 & 2.2 \\
\hline Total & 91 & 100.0 \\
\hline $\mathrm{M}=0.87 ; \mathrm{SD}=1.18 ; \mathrm{X}^{2}=102.25 ; \mathrm{df}=5 ; \mathrm{p}<0.001$ & & \\
\hline
\end{tabular}

Source: own research.

Analysis of the research results allowed to determine that almost half of the respondents do not reach for energy drinks (Table 1). Every tenth of the respondents admits to reach for such drinks frequently. Fewer people than it would be due to a random frequency distribution, reach for energy drinks several times a month, at least once a week, daily $\left(\chi^{2}=102.25 ; \mathrm{df}=5 ; \mathrm{N}=91 ; \mathrm{p}<0.001\right)$. Two people have admitted the daily intake of a drink of this type: No. 15 - emotionally-focused coping style, high self-efficacy; and No. 44 - emotional-focused coping style, low self-efficacy.

Young people reaching for energy drinks are aware of health risks which might result from it. These health hazards are listed in order of frequency: negative impact on heart function, presence of harmful substances, lots of chemistry, hypertension, accelerated heart rate, high caffeine or sugar levels, addiction, hyperactivity, liver damage, impaired renal function, leaching of nutrients from the body, sleep problems, dysfunction of the body.

In the opinion of students, particularly vulnerable to the loss of health due to reaching for energy drinks are: people with high blood pressure and heart diseases, children, adolescents and elderly people with disorders of the ionic economy, people with health problems, those who live fast, lead a stressful or sports life style, pregnant women, caffeine addicts, diabetics and those who mix energy drinks with alcohol.

Interesting from the research point of view has been the attempt to answer the question: Can reaching for energy drinks be one of strategies to deal with excess of duties and pressure of time? Analysis of the answers contained in the questionnaire addressed to the students allowed us to identify important factors from the 
point of view of functioning at the university. They were considered as difficult situations in the daily life of a student (ability to manage time, plan action, be responsible and systematic, or focused on social life).

Table 2. Dependence on energy drinks with declaring no responsibility for failure to perform a task within a specified period $(\mathrm{N}=91)$

\begin{tabular}{|c|c|c|c|c|c|c|}
\hline \multirow{3}{*}{$\begin{array}{l}\text { Statement: I do not mind when I } \\
\text { do not perform tasks at a certain time }\end{array}$} & \multicolumn{6}{|c|}{ Reaching for energy drinks } \\
\hline & \multicolumn{2}{|c|}{$\begin{array}{c}\text { Never/Occasio- } \\
\text { nally }\end{array}$} & \multicolumn{2}{|c|}{$\begin{array}{l}\text { Several times } \\
\text { a month }\end{array}$} & \multicolumn{2}{|c|}{$\begin{array}{l}\text { At least once } \\
\text { a week/Daily }\end{array}$} \\
\hline & $\begin{array}{l}\text { No. of } \\
\text { people }\end{array}$ & $\%$ & $\begin{array}{l}\text { No. of } \\
\text { people }\end{array}$ & $\%$ & $\begin{array}{l}\text { No. of } \\
\text { people }\end{array}$ & $\%$ \\
\hline Definitely disagree & 28 & 30.8 & 3 & 3.3 & 2 & 2.2 \\
\hline Rather disagree & 34 & 37.4 & 5 & 5.5 & 1 & 1.1 \\
\hline Rather agree & 7 & 6.6 & 1 & 1.1 & 2 & 2.2 \\
\hline Definitely agree & 5 & 5.5 & 4 & 4.4 & 0 & 0.0 \\
\hline Total & 73 & 80.2 & 13 & 14.3 & 5 & 5.5 \\
\hline
\end{tabular}

Source: own research.

There is a statistically significant correlation $(\mathrm{p}<0.05)$ between reaching for energy drinks and responsibility for the task at a given time (Table 2). Most of the respondents (68.2\%) are people who do not or hardly ever drink such beverages and feel responsible for the work done on time. Among the very frequent drinkers of energy drinks there is the same number of people ( 2 people) who are responsible and those who are not concerned about the deadline. Due to the low frequency of indications, it is difficult to recognize that the described dependence is a rule in the procedure and the use of energy drinks is a strategy of coping with time pressure.

In response to the second research question, an empirical analysis did not indicate the existence of a statistically significant relationship between reaching for energy drinks and experiencing lack of time, the ability to organize time properly, sense of duty and availability or work planning.

Subsequently, we sought different ways of coping with a difficult situation and a sense of self-efficacy by surveyed female students who reach for energy drinks with varying frequency.

Then, the relationship between the use of energy drinks and coping with the difficult situation and self-efficacy of the students was sought. In determining the 
level of self-efficacy, $46.2 \%$ of students reported high levels of self-efficacy, while $8.8 \%$ of them - low (Table 3 ).

Table 3. Self-efficacy level (N=91)

\begin{tabular}{|l|c|c|}
\hline \multicolumn{1}{|c|}{ Level of self-efficacy } & No. of people & $\%$ \\
\hline Low & 8 & 8.8 \\
\hline Average & 41 & 45.1 \\
\hline High & 42 & 46.2 \\
\hline Total & 91 & 100.0 \\
\hline $\mathrm{X}^{2}=24.68 ; \mathrm{df}=2 ; \mathrm{p}<0.001$ & \multicolumn{2}{|l}{} \\
\hline
\end{tabular}

Source: own research.

When referring to the content of the third research question, there was no statistically significant difference in self-efficacy and reaching for energy drinks (Table 4). In the indicated analysis, we used the Kruskal-Wallis significance of differences test. It can be assumed that the lack of significance of the differences may be related to the low representation of people with low self-efficacy level.

Table 4. Difference in the level of self-efficacy of people reaching for energy drinks at different frequencies ( $\mathrm{N}=91$; Kruskal-Wallis test)

\begin{tabular}{|l|l|c|c|}
\hline \multirow{5}{*}{ Self-efficacy } & \multicolumn{1}{|c|}{ Frequency of reaching for energy drinks } & No. of people & Average rank (\%) \\
\cline { 2 - 4 } & Never/Hardly ever & 73 & 47.53 \\
\cline { 2 - 4 } & Occasionally/Several times a month & 13 & 40.00 \\
\cline { 2 - 4 } & At least once a week/Every day & 5 & 39.30 \\
\cline { 2 - 4 } & Total & 91 & 100.00 \\
\hline & \multicolumn{2}{|l}{} \\
\hline
\end{tabular}

Source: own research.

Dealing with difficult and stressful situations is possible when people are convinced of their sense of self-efficacy and have worked out the right strategies. In the case of students, the stressful situation may be an examination session or combining studying with work and home duties. Subsequently, we analyzed the students' preferred styles of stress management. 
Table 5. Styles of coping with stress of the surveyed female students $(\mathrm{N}=91)$

\begin{tabular}{|c|c|c|c|}
\hline Styles of coping with stress & $\begin{array}{c}\text { The level of occurrence } \\
\text { of the style }\end{array}$ & $\begin{array}{l}\text { No. of } \\
\text { people }\end{array}$ & $\%$ \\
\hline \multirow{4}{*}{ Style focused on a task } & Low & 35 & 38.5 \\
\hline & Average & 30 & 33.0 \\
\hline & High & 26 & 28.6 \\
\hline & Total & 91 & 100.0 \\
\hline \multicolumn{4}{|l|}{$X^{2}=1.34 ; \mathrm{df}=2 ;$ n.i. } \\
\hline \multirow{4}{*}{ Style focused on emotions } & Low & 9 & 9.9 \\
\hline & Average & 38 & 41.8 \\
\hline & High & 44 & 48.4 \\
\hline & Total & 91 & 100.0 \\
\hline \multicolumn{4}{|l|}{$\mathrm{X}^{2}=23.1 ; \mathrm{df}=2 ; \mathrm{p}<0.001$} \\
\hline \multirow{4}{*}{ Style focused on avoiding } & Low & 36 & 39.6 \\
\hline & Average & 35 & 38.5 \\
\hline & High & 20 & 22.0 \\
\hline & Total & 91 & 100.0 \\
\hline \multicolumn{4}{|l|}{$\mathrm{X}^{2}=5.3 ; \mathrm{df}=2 ;$ n.i. } \\
\hline \multirow{4}{*}{$\begin{array}{l}\text { Style focused on engaging in substitu- } \\
\text { te activities }\end{array}$} & Low & 22 & 24.2 \\
\hline & Average & 44 & 48.4 \\
\hline & High & 25 & 27.5 \\
\hline & Total & 91 & 100.0 \\
\hline \multicolumn{4}{|l|}{$\mathrm{X}^{2}=9.39 ; \mathrm{df}=2 ; \mathrm{p}<0.01$} \\
\hline \multirow{4}{*}{$\begin{array}{l}\text { Style focused on searching for social } \\
\text { contacts }\end{array}$} & Low & 40 & 44.0 \\
\hline & Average & 35 & 38.5 \\
\hline & High & 16 & 17.6 \\
\hline & Total & 91 & 100.0 \\
\hline
\end{tabular}

Source: own research.

The data collected in Table 5 illustrate even distribution of styles that are focused on the task and the avoidance. Approximately $40 \%$ of students declare a low level of concentration on the task, and almost every third person presents a high level of such a style.

Every fifth woman pointed to a low level of focus on avoiding the task. Statistically significant results have emerged in the style focused on emotions - every 
second woman uses a high level of this style (Table 5). Similar research results are presented by Heszen-Niejodek (2000). The style focused on avoidance can, among others, be involved in engaging in substitute activities or looking for social contacts.

Level variation in occurrence of these coping strategies turned out to be statistically significant. Every second person presents the average level of involvement in substitute activities in difficult situations. Similarly, nearly half of the surveyed women pointed to the low need for social contacts as a strategy used in difficult situations.

Table 6. Difference in coping with difficult situations of using energy drinks at different frequencies ( $\mathrm{N}=91$; Kruskal-Wallis test)

\begin{tabular}{|c|c|c|c|}
\hline & $\begin{array}{l}\text { Frequency of reaching } \\
\text { for energizing drinks }\end{array}$ & $\begin{array}{l}\text { No. of } \\
\text { people }\end{array}$ & $\begin{array}{l}\text { Average } \\
\text { rank }(\%)\end{array}$ \\
\hline \multirow{4}{*}{ Style focused on task (SSZ) } & Never/Hardly ever & 73 & 46.67 \\
\hline & Occasionally/Several times a week & 13 & 45.50 \\
\hline & At least once a week/Daily & 5 & 37.50 \\
\hline & Total & 91 & 100.00 \\
\hline \multicolumn{4}{|l|}{ H Kruskal-Wallis $=0.57 ; \mathrm{df}=2 ;$ n.i. } \\
\hline \multirow{4}{*}{ Style focused on emotions (SsE) } & Never/Hardly ever & 73 & 45.45 \\
\hline & Occasionally/Several times a month & 13 & 50.77 \\
\hline & At least once a week/Daily & 5 & 41.70 \\
\hline & Total & 91 & 100.00 \\
\hline \multicolumn{4}{|l|}{ H Kruskal-Wallis $=0.59 ; \mathrm{df}=2 ;$ n.i. } \\
\hline \multirow{4}{*}{ Style focused on avoidance (SSU) } & Never/Hardly ever & 73 & 46.68 \\
\hline & Occasionally/Several times a month & 13 & 42.08 \\
\hline & At least once a week/Daily & 5 & 46.20 \\
\hline & Total & 91 & 100.00 \\
\hline
\end{tabular}

Source: own research.

The results in Table 6 provide an attempt to answer the fourth research question. Based on the analysis of mean ranks, no statistically significant difference was revealed in reaching for energy drinks by people with different levels of the presented style, based on the tasks, emotions and avoidance.

Reaching for energy drinks seems to be a way of coping with the pressure of time when performing certain duties, such as preparing for an exam. Examples 
of stressful situations included in the CISS questionnaire are not always related to activities which should be performed in a strictly defined time frame, as in the case of tasks resulting from the student role.

\section{CONCLUSIONS AND DISCUSSION}

1. Nearly half of the respondents do not reach for energy drinks, and every ninth of the tested students admits to reach for such beverages.

2. Young people who use energy drinks are aware of health hazards resulting from recourse to this type of drinks.

3. There was no statistically significant difference in reaching for energy drinks among people representing different levels of styles of coping with difficult situations.

4. There was no statistically significant difference in reaching for energy drinks among people with different levels of self-efficacy.

5. There is a statistically significant relationship between reaching for energy drinks and declaring no responsibility for failure to perform a task within the specified time frame.

6. There was no statistically significant relationship between the use of energy drinks and coping with overwork and pressure of time, including the correct organization of time, lack of time, dutifulness, availability and skills planning.

The researchers failed to find research works dealing with the issues they raised in the analyzed context and that makes discussing difficult. In the light of self-study, there were no differences in the frequency of consumption of energy drinks by students presenting different styles of coping with difficult situations. The literature on the subject indicates various reasons for using such drinks. A study conducted in 2011 among 92 students of Agricultural University and the University of Physical Education in Warsaw showed that $67 \%$ of respondents reached for energy drinks, mainly in order to reduce sleeplessness (45.2\%), especially during the examination session. The subjects experienced agitation $(72.9 \%)$, palpitations (32.2\%), and insomnia (25.8\%) after drinking. In the opinion of the majority of the respondents $(88.7 \%)$, these drinks are considered effective; half of the respondents considered them tasty although dangerous to health (Kopacz et al. 2012, p. 491). Kopacz et al. (2013, p. 49) have attempted to determine in what period the students of Agricultural University and the University of Physical Education in Warsaw consume the most energy drinks. It has been confirmed that students most commonly reach for them during exams; students of the University of Physical Education more often than students of Agricultural University also outside the session. Similarly, Semeniuk's (2011) studies show that more than 
$15.3 \%$ of students of Lublin University of Life Sciences used energy drinks during the session and these drinks were preferred by women (Błaszczyk et al. 2013, p. 818). The analysis of available studies confirms the fact that students are eager to reach for energy drinks during psychophysical effort (Michota-Katulska et al. 2014, p. 783).

The use of energy drinks probably depends neither on the ways of dealing with difficult situations nor on the level of self-efficacy. Nor does it appear that the students tried to thus increase their availability of coping with the obligations and time pressure. Energy drink is treated as an energy injection which is used to stimulate and prolong learning time while fighting sleepiness. It gives an opportunity to strengthen the forces, even in the face of sports struggle.

\section{BIBLIOGRAPHY}

Arria A.M., Caldeira K.M., Kasperski S.J., Vincent K.B., Griffiths R.R., O’Grady K.E. (2011), Energy Drink Consumption and Increased Risk for Alcohol Dependence, "Alcoholism. Clinical and Experimental Research”, Vol. 35(2), DOI: https://doi.org/10.1111/j.1530-0277.2010.01352.x.

Bajerska J., Woźniewicz M., Jeszka J., Wierzejska E. (2009), Częstość spożycia napojów energetyzujących a aktywność fizyczna $i$ występowanie nadwagi i otyłości wśród młodzieży licealnej, „Żywność. Nauka. Technologia. Jakość”, nr 4.

Błaszczyk E., Piórecka B., Jagielski P., Schlegel-Zawadzka M. (2012), Spożycie napojów funkcjonalnych $w$ grupie młodzieży z regionu Podkarpacia, „BROMAT. CHEM. TOKSYKOL. XLV", nr 1.

Błaszczyk E., Piórecka B., Jagielski P., Schlegel-Zawadzka M. (2013), Konsumpcja napojów energetyzujących $i$ zachowania z nią związane wśród młodzieży wiejskiej, „Problemy Higieniczno-Epidemiologiczne", nr 94.

Energetyzuja czy trują?, www.zdrowieapteka.pl/linki/mnz/artykuly/energetyzuja\%20czy\%20truja. pdf (access: 15.07.2017).

"Energy" drinks report. Doniesienie prasowe, www.gis.gov.pl/ckfinder/userfiles/files/EFSA/Energy\%20drinks\%20report.pdf (access: 15.07.2017).

Gathering consumption data on specific consumer groups of energy drinks, www.efsa.europa.eu/en/ supporting/pub/en-394 (access: 15.07.2017).

Heszen-Niejodek I. (2000), Stres i radzenie sobie - główne kontrowersje, [in:] I. Heszen-Niejodek, Z. Ratajczak (red.), Człowiek w sytuacji stresu. Problemy teoretyczne i metodologiczne, Katowice: Wydawnictwo Uniwersytetu Śląskiego.

Juczyński Z. (2000), Narzędzia pomiaru w promocji i psychologii zdrowia, Warszawa: Pracownia Testów Psychologicznych PTP.

Kopacz A., Wawrzyniak A., Hamułka J., Górnicka M. (2012), Badania uwarunkowań spożywania napojów energetyzujących przez studentów, „Roczniki Państwowego Zakładu Higieny”, nr 4.

Kopacz A., Wawrzyniak A., Hamułka J., Górnicka M. (2013), Evaluation of Energy Drink Intake in Selected Student Groups, „Roczniki Państwowego Zakładu Higieny”, nr 1.

Łagowska K., Woźniewicz M., Jeszka J., Posłuszny M. (2011), Ocena częstotliwości spożycia produktów, potraw i napojów o wysokiej wartości energetycznej przez młodzież szkolną o różnym poziomie aktywności fizycznej, „Studia Periegetica. Zeszyty Naukowe Wielkopolskiej Wyższej Szkoły Turystyki i Zarządzania w Poznaniu", nr 6. 
Michota-Katulska E., Zegan M., Sińska B., Kucharska A. (2014), Zachowania wybranej grupy studentów wobec napojów energetyzujących stosowanych w czasie wzmożonego wysitku psychofizycznego, „Problemy Higieniczno-Epidemiologiczne”, nr 95(3).

Reissig C.J., Strain E.C., Griffiths R.R. (2009), Caffeinated Energy Drinks - A Growing Problem, "Drug and Alcohol Dependence", Vol. 99.

Semeniuk W. (2011), Spożywanie napojów energetyzujących wśród studentów Uniwersytetu Przyrodniczego w Lublinie, „Problemy Higieniczno-Epidemiologiczne”, nr 92(4).

Strelau J., Jaworowska A., Wrześniewski K., Szczepaniak P. (2005), Kwestionariusz Radzenia Sobie w Sytuacjach Stresowych CISS. Podręcznik, Warszawa: Pracownia Testów Psychologicznych PTP.

Waszkiewicz-Robak B. (2008), Napoje funkcjonalne - trendy oraz składniki o ukierunkowanym działaniu zdrowotnym, „Agro Przemysł”, nr 5.

Wierzejska R., Jarosz M. (2011), Napoje energetyzujące a zdrowie - postęp wiedzy, „Medycyna Wieku Rozwojowego", nr 4, www.medwiekurozwoj.pl/articles/2011-4-13.html (access: 15.07.2017).

\section{STRESZCZENIE}

Dynamicznie zmieniająca się rzeczywistość stawia nam wciąż nowe wyzwania, stąd konieczność bycia mobilnym i dyspozycyjnym. W konsekwencji sięgamy po różne produkty zwiększające naszą wydajność, nierzadko kosztem własnego zdrowia. Badania przeprowadzono wśród studentów I roku kierunków humanistycznych UMCS w Lublinie. Do określenia zjawiska częstości sięgania przez badanych po napoje energetyzujące i stojących przed nimi zadań oraz obowiązków wykorzystano ankietę własnej konstrukcji, zaś do zdiagnozowania stylów radzenia sobie ze stresem i poczucia własnej skuteczności zastosowano CISS i GSES. Niemal połowa badanych nie sięga po napoje energetyzujące, a do częstego sięgania przyznaje się co dziesiąty z badanych. Młodzi ludzie, korzystając z tych napojów, mają świadomość zagrożeń dla zdrowia. Nie odnotowano istnienia zależności między sięganiem po napoje energetyzujące a stylami stosowanymi przez badanych w różnych sytuacjach trudnych i poziomem poczucia własnej skuteczności.

Słowa kluczowe: napoje energetyzujące; radzenie sobie w sytuacjach trudnych; poczucie własnej skuteczności 